\title{
Pedagogical features of the ethnocultural aspect of personality in literature
}

\section{Características pedagógicas do aspecto etnocultural da personalidade na literatura}

\section{Rasgos pedagógicos del aspecto etnocultural de la personalidad en la literatura}

\author{
Olga Stadnichenko $^{1}$ iD, Valentyna Kravchenko ${ }^{1}$ iD Oksana Protsenko $^{1}$ iD, \\ Mykola Stasyk $^{1}$ iD, Olena Olshanska ${ }^{1}$ iD
}

${ }^{1}$ Zaporizhzhia National University, Zaporizhzhia, Ukraine.

Corresponding author:

Olga Stadnichenko

Email: svrodch@ukr.net

How to cite: Stadnichenko, O., Kravchenko, V., Protsenko, O., Stasyk, M., \& Olshanska, O. (2021). Pedagogical features of the ethnocultural aspect of personality in literature. Revista Tempos e Espaços em Educação, 14(33), e16588.

http://dx.doi.org/10.20952/revtee.v14i33.16588

\begin{abstract}
The main goal of the study is to determine the main pedagogical aspects of the ethnocultural characteristics of the individual in the literature. There is a need for a cross-cutting humanization of education, strengthening the personal dimension in pedagogical science and practice. Orientation towards a person (a child, a youth, a student, a well-trained specialist) should become the main goal and content of the education system of the 21st century. The person must be put in the first place. To this end, education should contribute to a person's awareness of his own roots, his place in the world, the assimilation by each individual of the ethnoculture of the community as a way of his being, so that in the future he will be able to enter into a dialogue with other cultures, move freely in their space according to the principle "from knowledge and respect for one's own culture begins to respect other cultures, the desire to study the signs, symbols, codes of another community, to understand their stereotypes of behavior, the peculiarities of the world perception and worldview - the basis of tolerance and unity. "The study was carried out using the following theoretical methods: systems analysis and synthesis, induction and deduction, comparison, classification, generalization and systematization, idealization and abstraction. As a result, the main pedagogical aspects of ethnocultural personality traits in literature were identified.
\end{abstract}

Keywords: Culture. Ethnoculture. Literature. Pedagogical aspects. Pedagogy. 


\section{RESUMO}

O objetivo principal do estudo é determinar os principais aspectos pedagógicos das características etnoculturais do indivíduo na literatura. É necessária uma humanização transversal da educação, fortalecendo a dimensão pessoal na ciência e na prática pedagógica. A orientação para uma pessoa (uma criança, um jovem, um estudante, um especialista bem formado) deve se tornar o objetivo principal e o conteúdo do sistema educacional do século XXI. A pessoa deve ser colocada em primeiro lugar. Para tanto, a educação deve contribuir para a consciência da pessoa sobre suas próprias raízes, seu lugar no mundo, a assimilação por cada indivíduo da etnocultura da comunidade como um modo de ser, para que no futuro seja capaz de entrar em diálogo com outras culturas, movimentar-se livremente no seu espaço segundo o princípio "a partir do conhecimento e respeito pela própria cultura passa a respeitar outras culturas, o desejo de estudar os signos, símbolos, códigos de outra comunidade, para compreender os seus estereótipos de comportamento, as peculiaridades da percepção do mundo e cosmovisão - a base da tolerância e unidade. "O estudo foi realizado utilizando os seguintes métodos teóricos: análise e síntese de sistemas, indução e dedução, comparação, classificação, generalização e sistematização, idealização e abstração. Como resultado, foram identificados os principais aspectos pedagógicos dos traços de personalidade etnocultural na literatura.

Palavras-chave: Aspectos culturais. Etnocultural. Literatura. Pedagogia. Pedagógicos.

\section{RESUMEN}

El objetivo principal del estudio es determinar los principales aspectos pedagógicos de las características etnoculturales del individuo en la literatura. Es necesaria una humanización transversal de la educación, fortaleciendo la dimensión personal en la ciencia y la práctica pedagógicas. La orientación hacia una persona (un niño, un joven, un estudiante, un especialista bien capacitado) debe convertirse en el principal objetivo y contenido del sistema educativo del siglo XXI. La persona debe ponerse en primer lugar. Para ello, la educación debe contribuir a la toma de conciencia de la persona sobre sus propias raíces, su lugar en el mundo, la asimilación por parte de cada individuo de la etnocultura de la comunidad como forma de ser, para que en el futuro pueda entablar un diálogo con otras culturas, moverse libremente en su espacio según el principio "desde el conocimiento y respeto por la propia cultura comienza a respetar otras culturas, el deseo de estudiar los signos, símbolos, códigos de otra comunidad, a comprender sus estereotipos del comportamiento, las peculiaridades de la percepción y cosmovisión del mundo - la base de la tolerancia y la unidad. "El estudio se realizó utilizando los siguientes métodos teóricos: análisis y síntesis de sistemas, inducción y deducción, comparación, clasificación, generalización y sistematización, idealización y abstracción. Como resultado, se identificaron los principales aspectos pedagógicos de los rasgos de personalidad etnocultural en la literatura.

Palabras clave: Aspectos culturales. Etnoculturales. Literatura. Pedagogía. Pedagógicos.

\section{INTRODUCTION}

The formation of a new model of a modern school necessitates a thorough analysis and rethinking of the theoretical, methodological and conceptual foundations of training a future teacher. In the pedagogical encyclopedia, professional training is understood as a set of special knowledge, skills and abilities, qualities, work experience and norms of behavior that provide the opportunity for successful work in a particular profession.

As the analysis of literary sources shows, in a number of publications one can find different opinions on the problems of vocational training. So, the components of professional training are: arming with culture, which will allow you to find your place in life and will give you the opportunity to make independent decisions; updating the content and educational and methodological support for the training of teaching staff; the development of new technologies for vocational training will 
change the place of the student in the mass monotonous pedagogical reproduction. The formation of a creative, proactive, self-critical teacher will be carried out on the condition that the future specialist already during his studies will be familiar not only with the latest education technologies, but also with the highly professional use of the achievements of ethnopedagogy in the educational process of the new school. The personal world of a child develops from the individual to the spiritually practical experience of mankind with the aim of educating a person of culture capable of reproducing the natural and cultural environment, relying primarily on national culture.

The future teacher should remember that the ethnization of the child begins at preschool and primary school age, through participation in family customs and rituals, from folk songs, involvement in folk art; the cult of the home, family, hometown or village is formed, is the basis for the child's further awareness of himself as a part of the nation. As practice shows, the content of school subjects in elementary school is supplemented by the ethnographer. School textbooks, teaching aids for teachers and students are generously rich in folklore. Ukrainian folk tales are imbued with folk wisdom and contain ancient knowledge and ideas about life, their world around them, and hope for a better future. Play is of great importance in the life of a younger student. In play, the child first emotionally and then intellectually masters the system of human relations. The skill of the teacher and a well-thought-out methodology for conducting outdoor folk games will provide not only educational, but also cognitive and health-improving effect, help to attract schoolchildren to the origins of national culture and spirituality. Today, it is necessary to organize a purposeful ethno-cultural training of future teachers, to form their subjective position as a carrier of ethnoculture (Amhag et al., 2019; Budnyk et. al., 2021; Kachak et. al., 2021).

The educational content of higher pedagogical institutions should use an ethnocultural component filled with the historical, cultural, ethnographic, and national heritage of all people and helps to form a citizen capable of a conscious public choice. In order to understand the relevance of the named problem, we will define the essence of the concept of "ethnocultural education" - this is an important part of modern education, which contributes to the assimilation of knowledge about different cultures by students of educational institutions, clarification of the general and special in traditions and customs, attraction to the cultural values of peoples and way of life, upbringing student youth in a spirit of respect for other cultural systems.

Ethno-cultural provides a clear direction to the process in the higher pedagogical school, combining disparate disciplines into a system; focuses not on the didactic side of vocational training, but on the moral aspects of the interaction of the subjects of the pedagogical process, the creation of conditions for the formation of a specialist as an independently thinking personality, capable of self-expression, self-creation, self-realization.

Professional training of the future teacher in the context of the ethnocultural paradigm should be focused on such activities in the university as solving pedagogical problems, modeling fragments of educational activities, business games, auctions of folklore ideas, improvisation contests, holding seminars, scientific and practical, methodological conferences of young scientists devoted to ethnopedagogical problems, as well as the inclusion in the content of education of the system of knowledge about the culture and life of ethnographic groups. It is effective to attract students to research work, write master's, diploma, course projects, abstract papers, scientific articles, design classes on an ethnocultural topic, activate their activities by various group (trainings, circles, interest clubs, sections) and collective (pedagogical reading, discussion with teachers of academic disciplines of one problem, but from the standpoint of various sciences; discussions on ethnocultural topics).

\section{METHODOLOGY}

The main goal of the study is to determine the main pedagogical aspects of the ethnocultural characteristics of the individual in the literature. For this, a number of methods were applied, which 
form the research methodology. The study was carried out using the following theoretical methods: systems analysis and synthesis, induction and deduction, comparison, classification, generalization and systematization, idealization and abstraction.

\section{RESULTS AND DISCUSSION}

The social and economic development of modern society contributes to the attraction of representatives of different peoples, regions, confessions, cultures to active interaction. Not only further scientific, technical and socio-economic progress, but also the existence of mankind in difficult ecological, demographic, economic and other conditions, largely depends on their interaction, mutual relations, and mutual assistance. This explains the growing interest of society in multicultural and ethnic processes, and justifies the socio-economic need to prepare modern youth for a future worthy, safe and tolerant life in a real multiethnic world. Such training consists in fostering tolerance for someone else's way of life, other people's customs, traditions, other feelings, thoughts, ideas; respect for representatives of other nationalities, respect for different cultures and religions; in the preservation and development of the achievements of the peoples inhabiting Ukraine, as well as the search for effective ways of interaction between different ethnocultures, especially in the context of bringing people of different nationalities closer together and preventing interethnic conflicts that take place against the background of the political life of our state. It is education that plays a significant role in resolving this issue. In the educational space, a person delves into the ethnic culture of his people, learns the national identity of the region, and through them is drawn to the world common human culture. The conductor of the cultural heritage of ethnic groups, nations, communities is a teacher who is called upon to attract the future generation to numerous cultural values, traditions, to be the bearer of his own ethno-national culture and inspire the formation of ethno-cultural awareness of the younger generation.

In this regard, society makes qualitatively new requirements for the training of teachers. Along with the general professional competence of teachers, the issue of the formation of the ethnocultural competence of future specialists in the field of education and, first of all, those who are called upon to act in a multiethnic environment, was on the agenda (Moldabekova et. al., 2021; Mukhametshin et. ail., 2021).

Ethnocultural competence aims at ethnocultural training and requires the future teacher of fine arts to acquire:

- ethno-pedagogical education - a system of knowledge that underlies the implementation of the learning process on the basis of traditional pedagogical culture in accordance with the modern humanistic orientation of the educational system;

- ethnopedagogical outlook - awareness of topical problems of education and upbringing on the basis of traditional pedagogical culture and proven ways of solving them;

- ethno-pedagogical thinking - the formation of a style of thinking focused on finding ways to optimally organize the learning process based on people's experience in this area;

- ethno-pedagogical experience - the experience of making literate ethno-pedagogical decisions.

Sciences singled out the following components in the structure of ethno-pedagogical competence:

- the goals of mastering academic disciplines on the basis of traditional pedagogical culture, their content and priority in today's conditions;

- psychological mechanisms of mastering ethno-pedagogical knowledge and ways of using it in the learning process;

- ethnopedagogical concepts and factors directly present in school textbooks or related to them; 
- criteria for assessing didactic and developmental values of different ethnopedagogical content;

- the most typical ways of mastering the traditional pedagogical culture (tools, organizational forms of training and control).

However, we note that the above components of the structure must be constantly updated and revised in accordance with the requirements of modern education, to orient future masters of fine arts towards the development and socialization of the individual in a multiethnic state. That is why the actual principles of building and developing national education in conditions of polyethnicity are determined, namely:

- inclusion of students in their native ethnocultural tradition;

- implementation of the constitutional right of upbringing and education in the native language;

- the transition from their own ethnoculture to the recognition and understanding of the cultures of ethnic groups living together in conditions of polyethnicity and the subsequent perception of world artistic values;

- dynamic unity of three foundations: ethnic, national, universal;

- the principle of variability in the construction of university art education.

The ethnocultural competence of a master's student is an element not only of art education and artistic orientation of education, but also of his everyday consciousness and everyday behavior. Therefore, it has a cross-cutting nature and covers all spheres of life, manifests itself mainly at the subconscious level.

Modern trends that characterize the European educational space of the XXI century are evidenced by the approval of new approaches to the process and results of the educational impact on the individual, the reassessment of traditional educational paradigms, taking into account the requirements of the present, globalization changes, and attempts to search for innovative ways of pedagogical activity are noticeable. Consequently, the system of values on which the pedagogical process is oriented has a cultural and historical character. Therefore, interstate integration in the modern world community should be carried out taking into account the traditions of each nation, because the formation and development of a person are inseparable from the people's everyday educational environment. Therefore, we consider the problem of ethnocultural education of a future specialist to be relevant in the context of his professional training. For a modern higher educational institution, it is extremely important that the principle of cultural conformity in education is not limited solely to the trivial transfer of ready-made knowledge about ethnoculture, but provides for the development of creative thinking, national feelings of students. The intellectual creativity of a nation experiences development only if national education is provided with a continuous transfer of the best experience of the past people from generation to generation. And only in this way, national education, absorbing the cultural European and world values, will be able to bring its ethnocultural modifications to the achievement of civilization (Vuorikari et. al., 2016; Ospanova et. al., 2021; Cordeiro et. al., 2021).

The ethnocultural education of future teachers is manifested in the fact that they study the specifics of raising children in accordance with folk traditions and customs - the transfer of sociocultural experience, work skills and abilities is carried out in a natural relaxed atmosphere through well-known norms. Life itself makes the child learn, acquire the appropriate experience. The people's heritage of traditions, customs and rituals serves as a means of achieving educational goals. Thus, a person is first aware of the content of the concepts of "morality", "spirituality", "industriousness" and others directly through the practice of appropriate behavior. The quality of a person's preparation for various spheres of life, the direction of his spiritual interests, the satisfaction of cognitive needs are largely determined by family and social educational traditions. 
We believe that the study of the technology of using electronic projects in education, that is, the forms of educational and educational activities of a student and teacher using information and communicative teaching aids, is positive in the aspect of the use of pedagogical innovations in the ethnocultural education of future teachers. Work on such a project involves individual or group cooperation within a certain period. The main feature of an electronic project is its interdiscipline, that is, opportunities for students to improve their knowledge from different areas of scientific knowledge - language, history, art, culture, and the like. We believe that the participation of students from different countries in electronic educational projects will serve not only to enrich their knowledge of foreign history, art of different peoples, but will also help to raise the level of foreign language culture, to contribute to the formation of interethnic tolerance. On the basis of foreign experience, some European educational projects are being successfully implemented today. A significant number of projects have been created in the information space with the involvement of students and teachers from different countries of the world for the exchange of information, the development of communicative culture, the establishment of social contacts, the development of multicultural thinking, a sense of the importance of one's own opinion in the global world, serve as prerequisites for their development, because they, because of their isolation in oneself and unwillingness to make contact can much more easily communicate via the Internet (Fontes \& Santos, 2020; Santos \& Rios, 2021; Yarullin et. al., 2018; Yushchenko et. al., 2021).

An effective aspect of such work is attracting students to research work (master's, diploma, course projects, abstract papers, scientific articles), creating an individual database of ethnocultural issues, activating their activities by various group (trainings, circles, interest clubs, sections ) and collective (pedagogical readings, discussions with teachers of academic disciplines of one problem, but from the standpoint of various sciences; discussions on ethnocultural topics) forms of work in teaching the humanities. The main criterion for preparing students for ethnocultural activities is their ability to work in a multinational environment, striving to solve and prevent interethnic problems, harmonize national relations. Proceeding from the fact that his scientific activity in the conditions of a higher educational institution, depending on each specific case, is of a planned, voluntary or obligatory nature, it is advisable to promote in every possible way the voluntary participation of future specialists in competitions, olympiads, conferences. The leading place in the system of their professional training belongs to the independent search and ethnographic activity of approximately the following content: to study the peculiarities of embroidery in their region; to write down the legends and beliefs about labor associated with folk crafts and trades, to determine their place in the content of school education; collect a collection of old household items (dishes, rare tools, household items, decorative items) and carry out their historical and local history analysis; to study little-known labor customs and rituals of a particular ethnic group, to determine their functions in the upbringing of modern children; systematize folk humorous creativity (songs, poems, anecdotes, sayings) and analyze their educational opportunities. Participation in search work will enrich students' ideas about the main elements of scientific research (definition of its object, subject, goals, objectives, formulation of a hypothesis, etc.), the choice and application of its methods, in particular observation, questioning, rating and self-assessment method, experiment, statistical methods, etc.

We consider the readiness of students for professional activity in an ethnocultural environment to be the criterion of their ethnocultural competence, which is manifested in the ability to apply professional knowledge and skills in a specific ethnic environment and value attitude to the corresponding activity. An indicative model of ethnocultural education includes: awareness of sociocultural identity (identification level), mastering the system of knowledge about the multicultural environment and correction of intolerant attitudes of an interethnic nature (cognitive level) and the formation and development of ethnocultural interaction skills (behavioral-activity level). The ethno-cultural upbringing of a modern student is manifested in an active cognitive 
activity of a corresponding nature, the ability to determine the tolerant behavior of people who differ in social, racial, ethnic, religious and other characteristics. The teacher's activity in the context of a competence-based approach to organizing the pedagogical process involves careful coverage of the importance of the foundations of various branches of scientific knowledge for the development of civilization, fiction, works of art, achievements of world culture, education on the life examples of outstanding people. The effectiveness of ethnocultural training of students in a higher educational institution is determined by a number of psychological and pedagogical conditions: ethnocultural orientation of the educational environment of an educational institution; implementation of intersubject communications; motivational-value attitude to pedagogical activity in the ethnological space and taking into account the principles of consistency, accessibility, humanity, ethnization, culture-like, nature-like, emotionality, democratization. The legacy of family educational traditions is a powerful means of forming the ethnocultural competence of student youth, in particular, their ideas about the national values and priorities of each country, a sense of patriotism, civic consciousness, spirituality, and interethnic tolerance. Pedagogical innovations in education, in particular, project activities, serve as a means of developing students' skills to lead social contacts in information media, critically assess negative trends in society, and respect representatives of other social spheres and cultures.

It should be understood that ethnocultural competence or personal incompetence is clearly and socially significant manifested at the intersection of cultures, where various conflicts may arise related to understanding, adequate perception of objects, phenomena, processes of the corresponding culture. It must be remembered that against the background of a decrease in the general ethnocultural competence in modern industrial society, phenomena of social lack of demand for this quality are revealed. Therefore, the level of ethnocultural competence or incompetence of a master student is determined by both individual and social factors. Referring to the theoretical analysis of philosophical, psychological, pedagogical, ethnopedagogical literature and our own practical experience, it seems appropriate to us to highlight the following directions of the formation of ethnocultural competence of a master of fine arts:

1. Ethnocultural identification of a teacher includes two characteristics: - objective - cultural basis; - subjective - self-assignment;

2. Inclusion in creative pedagogical activity through "immersion" in the world of ethnoculture;

3. Ethnocultural theoretical training of masters as the basis of readiness for the implementation of ethnocultural education. Ethnocultural identification is currently marked as identification, assimilation of oneself with members of a given ethnic community; the process of comparing and comparing the subject of a given ethnic community with the subjects of this and other communities.

The emotional and cognitive process of a subject uniting himself with other representatives of an ethnic group, a positive value attitude to history, culture, national traditions and customs of his people, to his ideals, language, territory of residence of an ethnic group, its statehood was called ethnic identity or ethnicity. Markers of ethnic self-identification are: 1) external reference pointsstimuli (ethnotype, speech; culture, family, feeling of "small homeland"; community of traditions, customs; epic, history of ethnos; famous ancestors) 2) internal reference points: self-awareness, well-being in this ethno-middle-class ; internally ethnic affinity; emotional connection with an ethnic community; personal choice of decision. Speaking about the influence of ethnocultural conditions on the socialization of a person, two groups of features can be distinguished: living room (biologicalphysical) and mental (fundamental spiritual properties). The mentality of an ethnos is "a deep spiritual structure characteristic of an ethnos as a large group of people, formed in certain climatic, historical and cultural conditions". 
The mentality of an ethnos determines the ways of seeing and perceiving the surrounding world at the sensory and pragmatic levels inherent in its units. The conditions for subconscious assimilation of the mentality of an ethnic group are: thorough knowledge of the native language; ethnic concept of personality and its upbringing national self-awareness, manifested in national identification, in the formation of ideas about the typical features of their ethnic community, its integrity; in the awareness of the commonality of the historical past, ideas about the native land, the culture of the people, in particular, art. Gradual inclusion in the creative pedagogical activity of a national educational institution by "immersion" in the world of traditional culture is the second direction of the formation of the ethnocultural competence of a master student. We see the third direction of the formation of ethnocultural competence of a master of fine arts in the theoretical training of a student in the field of folk pedagogy, ethnopedagogy and ethnopsychology, artistic culture and art as the basis of readiness for the implementation of ethnocultural education. Thus, the indicated directions of the formation of ethnocultural competence make it possible to identify and characterize the psychological and pedagogical foundations of the ethnocultural competence of a master of fine arts: optimal nature-appropriate development of all spheres of personality cognitive, moral-volitional, activity-practical, emotional.

2. Ethnocultural competence is characterized by the level of assimilation by the future teacher of knowledge about the culture of the ethnic group, the interiorization of its values, principles, meaning of existence, theoretical and practical readiness of the teacher to translate values that have a pronounced humanistic orientation in practical pedagogical and artistic activities.

3. Ethnocultural competence allows the future teacher to implement the fundamental provisions of ethnopedagogy in professional activity, optimally taking into account the ethnocultural and ethnopsychological characteristics of community units, their artistic culture.

The pedagogical environment for the formation of students' ethnocultural competence is a single field, a space in which the process of its formation takes place; general approaches; the sole purpose of the activities of teachers, students and representatives of national minorities; evaluating the actions of all participants in the pedagogical process. Unity is a subordinate goal setting, the task of solving a given problem. The pedagogical environment characterizes the atmosphere where the principles of humanity, mutual trust and mutual assistance actually appear; the climate of personal safety for each participant in the pedagogical process; opportunities for all-round stimulation of creative initiative in all types of educational and scientific activities. The pedagogical environment determines the central element of technology, occupies the goal, process, result and perspective of the formation of ethnocultural competence and manifests itself and has its own characteristics at all stages of ethnocultural work with students. The central element of technology is characterized by content and organizational interconnection, interaction with each other and other elements of ethnocultural training. The general goal of the technology provides for the formation of ethnocultural competence of students during their studies at the pedagogical university. The process of forming ethnocultural competence is aimed at achieving a common goal, it consists in the interaction of teachers, students and representatives of national minorities. It carries three interrelated stages: preparatory, basic and generalizing. The end result of this process presupposes the formation of students' ethnocultural competence as an integrated education, the unity of personal, epistemological, operational, procedural, integrative-evaluative and projective components, ensures productive ethnocultural activity and creative realization of the future teacher.

The positive result of the formation of the ethnocultural competence of students is closely related to the prospect, which consists in the active perception by future teachers of the actual problems of the current state of the ethnoculture of national minorities, in a constant orientation in their future work on the universal values and traditions of different ethnic groups; in tolerance, lability, behavior correction in non-standard interethnic situations; in the presence of deep and solid 
knowledge about the content of the culture of ethnic groups; in possession of sufficient ethnocultural skills; in the ability to realize and evaluate the adequacy of one's own pedagogical actions and forms of behavior in professionally significant situations of an ethnocultural nature; in the presence of a stable need for self-education; self-education, self-realization in a multiethnic environment. The components of the central element of the technology for the formation of ethnocultural competence of students are implemented in three aspects: educational, upbringing and practical. The educational aspect consists in the theoretical training of future teachers on the ethnoculture of national minorities in a particular region. It is implemented in the process of studying by students a specially developed course devoted to both the issue of the ethnic culture of national minorities in a particular region and the problem of ethnocultural work in educational institutions; in cooperation with information and cultural centers of ethnic groups and the like. The educational aspect is aimed at instilling in students a sense of patriotism, citizenship, respectful attitude towards people of different nationalities, in their cultural achievements, at the formation of a culture of interethnic communication among future teachers. This aspect is realized in purposeful educational work with students in the conditions of a pedagogical university and in close cooperation with representatives of national minorities (organization of national holidays, cultural festivals of ethnic groups, folklore circles, etc.). The purpose of the practical aspect is to create conditions for the self-realization of future teachers as professionals in a multiethnic environment through teaching practice in educational institutions, real participation in the cultural life of ethnic groups. Based on the specifics of the educational process at a pedagogical university in a multiethnic environment, its organization is made by normative and methodological support, means, forms, methods of ethnocultural work, cultural ties with national minorities of a particular region, active interaction of teachers, students and representatives of ethnic groups.

The positive effectiveness of the process of forming students' ethnocultural competence is achieved through pedagogical interaction. We understand this phenomenon as the process of the formation of subjective and cognitive experience by the subjects of the process of teaching, upbringing and joint practical activities aimed at the formation of ethnocultural competence of students. The subjects of interaction are teachers, students, representatives of national minorities, preschool educators, teachers, children, parents and others.

The technology of formation of ethnocultural competence of students of a pedagogical university is aimed at the gradual formation of components of ethnocultural competence. Stage I preparatory. The purpose of this stage is to form the personal component of ethnocultural competence. To achieve this goal, the following tasks are performed: 1 ) the formation of students' national self-awareness; 2) the formation of a primary understanding of the culture of ethnic groups; 3 ) interest in studying the ethnocultural heritage of national minorities compactly living in a particular region; 4) creating conditions for future teachers to understand the importance of cultural traditions of ethnic groups in the formation of spirituality, tolerance, patriotism of the younger generation; for students' awareness of the personal significance of studying the ethnoculture of national minorities, for their own spiritual development, the formation of ethnocultural oriented attitudes in the context of educational activities.

\section{CONCLUSION}

In the context of European integration, the goal of higher education for master students should be a person's awareness of his own roots, his place in the world, the assimilation by each individual of the ethnoculture of the community, the culture of interethnic communication. Ethnocultural competence as a driving mechanism for an adequate attitude to polyethnicity is intended to educate in the masters of literature the sphere of material and spiritual artistic culture, which is expressed in ethnopedagogical education, ethnopedagogical outlook, ethnopedagogical thinking, ethnopedagogical experience. The following main directions of the formation of 
ethnocultural competence of the Master of Literature can be distinguished: ethnocultural identification, which can be objective (cultural basis) or subjective (self-ascribing) "Immersion" into the world of ethnoculture by means of inclusion in creative pedagogical activity; ethnocultural theoretical training of masters as the basis of readiness for the implementation of ethnocultural education.

As a result, the main pedagogical aspects of ethnocultural personality traits in literature were identified. We consider the study of structural components and levels of formation of ethnocultural competence of a student-master of literature as prospects for further research.

Authors' Contributions: Stadnichenko, O.: conception and design, acquisition of data, drafting the article, critical review of important intellectual content; Kravchenko, V.: onception and design, acquisition of data, drafting the article, critical review of important intellectual content; Protsenko, O.: onception and design, acquisition of data, drafting the article, critical review of important intellectual content; Stasyk, M.: onception and design, acquisition of data, drafting the article, critical review of important intellectual content; Olshanska, O.: onception and design, acquisition of data, drafting the article, critical review of important intellectual content. All authors have read and approved the final version of the manuscript.

Ethics Approval: Not applicable.

Acknowledgments: Not applicable.

\section{REFERENCES}

Amhag, L., Hellström, L., \& Stigmar, M. (2019). Teacher Educators' Use of Digital Tools and Needs for Digital Competence in Higher Education. Journal of Digital Learning in Teacher Education, 35(4), 203-220.

Budnyk, O., Kachak, T., Blyznyuk, T., Rostykus, N., \& Boiko, H. (2021). Printed and e-book: problems of choice of modern students of the university. Revista Tempos e Espaços em Educação, 14(33), e15913. https://doi.org/10.20952/revtee.v14i33.15913

Cordeiro, E. P. B., Marques, M. M. C., \& Costa, M. T. N. (2021). Socio-emotional education: paths to inspire studies, research and practices. Revista Tempos e Espaços em Educação, 14(33), e13729.

https://doi.org/10.20952/revtee.v14i33.13729

Fontes, N. S., \& Santos, F. A. (2020). The absence of literature in the National Curricular Common Base for high school. Revista Tempos e Espaços em Educação, 13(32), 1-23. https://doi.org/10.20952/revtee.v13i32.14395

Kachak,T., Budnyk, O. \&Blyznyuk, T. (2021). Development of reading culture of school children: results of theoretical and empirical research. Revista Inclusiones, 8, 62-76.

Moldabekova, S. K., Sakhariyeva, A. Z., Bulatbayeva, K. N., Karekeevna, D. G., \& Karisovna, Z. A. (2021). A model of forming polylingual speech culture and communicative competence as a condition for teachers' training. Revista Tempos e Espaços em Educação, 14(33), e15616. https://doi.org/10.20952/revtee.v14i33.15616

Mukhametshin, A. A., Nasibullov, R. R., \& Adilova, V. K. (2021). Method of designing technology for future teacher intellectual work culture formation. Revista Tempos e Espaços em Educação, 14(33), e15250.

https://doi.org/10.20952/revtee.v14i33.15250

Ospanova, Zh., Tolybayeva, K., Nurkenova, S.K., Duisekova, K.K. \& Baltabayeva, G. (2021) Lingua and culture study research on indirect communication cognitive metaphor. Xlinguae. European Scientific Language Journal, 13(2), 157165.

Santos, M. H. S. R., \& Rios, J. A. V. P. (2021). Education and cultural differences: boundary educational practices in basic education. Revista Tempos e Espaços em Educação, 14(33), e13670.

https://doi.org/10.20952/revtee.v14i33.13670

Vuorikari, R., Punie, Y., Carretero Gomez, S. \& van den Brande, G. (2016). DigComp 2.0: The Digital Competence Framework for Citizens. Publications Office of the European Union, JRC101254. https://doi.org/10.2760/38842

Yarullin, I.F., Nasibullov, R.R., \& Khuziakhmetov, A.N.(2018).The Problem of Prospective Teachers' Active Citizenship Development. Modern Journal of Language Teaching Methods, 8(10), 334-340 . 
Yushchenko, N. S., Pokivaylova, E. B., Cheshenko, L. I., Ershova, O. V., \& Manuilov, V. (2021). Forming a culture of interpersonal relationships of senior preschoolers by means of art and play activities. Revista Tempos e Espaços em Educação, 14(33), e16135. https://doi.org/10.20952/revtee.v14i33.16135

Received: 11 July 2021 | Accepted: 12 September 2021 | Published: 19 November 2021

(c) (†)

This is an Open Access article distributed under the terms of the Creative Commons Attribution License, which permits unrestricted use, distribution, and reproduction in any medium, provided the original work is properly cited. 